\title{
Zeszyty PRASOZNAWCZE
}

Kraków 2017, T. 60, nr 1 (229), s. 119-136

doi: 10.4467/22996362PZ.17.010.6776

www.ejournals.eu/Zeszyty-Prasoznawcze/

\section{JAK BADAĆ PRASĘ DRUGIEGO OBIEGU?}

\author{
KONRAD KNOCH \\ Uniwersytet Gdański / Europejskie Centrum Solidarności
}

\section{ABSTRACT \\ How to research the underground press?}

The second circuit press is one of the most important historical sources to describe modern Polish history. The studies call for a holistic approach, i.e. the overall research of individual newspapers or thematic exhaustive comparative analysis, carried out by selecting the broadest possible research sample. In the first stage there should be wide queries conducted in order to determine the actual state of research on the topic that interests us. In the second stage a detailed analysis of the content of a newspaper or newspapers must be undertaken, through which a thematic categorization key is developed. For each key-topic selected texts are assigned. Then we measure the area of individual texts on a certain topic by number of pages $\mathrm{or}_{\mathrm{cm}}{ }^{2}$. We provide statistical reports serving as a starting point for substantive analysis of texts from the second circuit press. In press we also look for information on the origin of the newspapers, people or environments issuing them, organizational problems etc. The "conversation" of the researcher with the press becomes the preparation for interviews with its creators, authors. Then we start searching for editors or underground printers preceded by the preparation of a comprehensive and exhaustive questionnaire. The next step is to call the notation of sound or film with the people we were able to reach, and who are often (in the absence of archival materials) the only source of information enabling us to work on underground publications. The investigator becomes a mediator in the dialogue between the press and its creator. Another important link in the research on illegal publishing is the analysis of archival materials - primarily operational documents of the Security Service that are stored in the Institute of National Remembrance.

Adres do korespondencji: Uniwersytet Gdański / Europejskie Centrum Solidarności, Wydział Nauk Społecznych, Instytut Filozofii, Socjologii i Dziennikarstwa, Zakład Teorii, Historii i Języka Mediów; ul. J. Bażyńskiego 4, 80-309 Gdańsk; k.knoch@ecs.gda.pl 
It is a specific research triangle: analysis of the content of the press, conversation with its creators and analysis of archival documents. It allows you to make a chronicle record of the past reality and to save an important part of the modern Polish history from oblivion.

Keywords: second circuit, underground press, samizdat, democratic opposition, modern history of Poland (PRL), oral history

\section{Wstęp}

Od niemal dziesięciu lat w swojej pracy naukowej zajmuję się badaniem prasy drugiego obiegu w Polsce. W ciagu tego okresu dokonał się gigantyczny postęp związany przede wszystkim z digitalizacją zbiorów drugoobiegowych, opracowywaniem poszczególnych tytułów w postaci haseł encyklopedycznych i słownikowych, artykułów naukowych czy prac od licencjackich po doktorskie. Rozszyfrowano wiele postaci, odsłonięto mechanizmy funkcjonowania zespołów redakcyjnych i druku oraz kolportażu poszczególnych tytułów. Nadal jednak sporo zostało do zrobienia. W niniejszym tekście chciałbym przedstawić problemy, jakie napotyka badacz, analizując zjawisko drugiego obiegu w Polsce, wskazać sposoby ich przezwyciężenia oraz pokazać, w jaki sposób można badać nielegalną prasę wydawaną w okresie PRL.

\section{Problemy badawcze}

Aby odpowiedzieć na pytanie, jak badać prasę drugiego obiegu, konieczne jest uświadomienie sobie głównych problemów badawczych. Pierwszym jest definicja prasy drugiego obiegu. Dotychczasowe określają jedynie drugi obieg: „wszystko, co powstało przeciw czerwonemu”, ,gra z cenzurą”, „,każdy druk niepoddany kontroli cenzorskiej”, ,alternatywny obieg wydawniczy wobec rynku państwowego i cenzury” czy wreszcie ,zorganizowane wydawanie książek, broszur i czasopism poza cenzurą" (zob. np. Siekierski 1992, s. 285-286). Mamy też mocno rozbudowaną definicję zaproponowaną przez Krzysztofa Łabędzia i Beatę Dorosz, którzy mówią, iż są to: ,publikacje niepoddawane cenzurze państwowej, powstające w efekcie funkcjonowania oficyn wydawniczych działających wbrew instytucjonalnej kontroli partyjno-państwowej. Obieg ten można określić jako polityczny" (Łabędź 1997, s. 9). Dotychczasowe definicje są często niezbyt precyzyjne czy prawidłowe. Drugi obieg nie zawsze był wydawany przez oficyny wydawnicze, nie zawsze był polityczny, różny był też stopień jego ,,zorganizowania". Alternatywny obieg wydawniczy nie podkreśla nielegalności drugiego obiegu. W literaturze przedmiotu zupełnie brakuje określenia, czym jest sama prasa drugiego obiegu. Mamy również mnogość pojęć: prasa tajna (używane błędnie, bowiem odnosi się tylko do okresu powstania styczniowego), prasa konspiracyjna (również używane błędnie, raczej odnosi się do okresu I i II wojny światowej 
i tuż po niej), prasa podziemna (częściej stosowane w okresie stanu wojennego i latach 80.), prasa opozycyjna, antykomunistyczna, prasa niezależna, prasa bezdebitowa (nieocenzurowana), samizdat i bibuła. Dla jednych bliższe jest określenie ,prasa bezdebitowa”, kładące nacisk na kryteria formalne, czyli ukazywanie się poza zasięgiem czy wbrew cenzurze (Rudka 2001, s. 10). Dla innych bliższe jest określenie „prasa drugiego obiegu”, kładące nacisk na wydawanie jako ruch społeczny i alternatywny obieg informacji wobec oficjalnego - komunistycznego (Sowiński 2011, s. 1-14). Ostatecznie w polskiej historiografii najszerzej przyjęło się właśnie określenie „drugi obieg”. Niezależnie od tego, czy inne określenia są bardziej trafne czy precyzyjne, chyba należy się z tym faktem pogodzić. Nie bardzo wiadomo, kto i kiedy je wymyślił (wprowadził). Andrzej Friszke na moment jego powstania (czy raczej odrodzenia) wskazuje wrzesień roku 1976 (Swierczyńska 1995, s. 5-12)1, Siekierski pisze, że data ta nie budzi wątpliwości jako początek zorganizowanego wydawania poza cenzurą (Siekierski 1992, s. 285). Warto jednak dołożyć do tego tradycje Biuletynu wydawanego przez nielegalną organizację „Ruch” pod koniec lat 60 . Najszerzej pojęcie drugiego obiegu rozpowszechniło się w latach 80 . w mediach reżimowych jako alternatywna czy druga struktura życia (nie tylko medialna) (Siekierski 1992, s. 17). Osobiście zamiennie używam go z określeniem ,prasa podziemna”, które wskazuje na konspiracyjne metody przygotowywania i wydawania nielegalnej prasy wbrew i przeciwko komunistycznemu reżimowi (a nie w warunkach okupacji).

W związku z tym chciałbym zaproponować dwie definicje prasy drugiego obiegu. Pierwsza, węższa, brzmiałaby: ,publikacje periodyczne lub mające być w zamierzeniu wydawane periodycznie w latach 1969-1989, z naruszeniem dekretu o utworzeniu GUKPPiW lub ustawy o kontroli publikacji i widowisk, a także innych przepisów wykonawczych, najczęściej opatrzone tytułem albo nazwą, numerem i przynajmniej rokiem wydania”. Definicja ta obejmowałaby zatem gazety i czasopisma, ale również biuletyny zakładowe wydawane w okresie Solidarności, jak również pisma innych organizacji związkowych, studenckich, np. NZS. Często były one teoretycznie wydawane legalnie, z zamiarem wykorzystania ich do użytku wewnętrznego, ale w rzeczywistości zawarte w nich treści znacząco wybiegały poza ramy dozwolone zapisami prawa, a same pisma były kolportowane nie tylko w zakładzie pracy. Stawały się nośnikiem solidarnościowej rewolucji w całej Polsce. W normalnych warunkach państwa komunistycznego nie zostałyby dopuszczone do publikacji.

Druga definicja, szersza, oparta na zapisach ustawy Prawo prasowe, brzmialaby: „Publikacje periodyczne lub mające być w zamierzeniu wydawane periodycznie w latach 1969-1989, z naruszeniem dekretu o utworzeniu GUKPPiW lub ustawy o kontroli publikacji i widowisk, a także innych przepisów wyko-

${ }^{1}$ Natomiast genezy Friszke szuka już w wydarzeniach z marca 1968 r., kiedy grupa tzw. „Komandosów" na Uniwersytecie Warszawskim pisała ulotki wyjaśniające sens protestu przeciw zakazowi dalszego przedstawiania „Dziadów”. 
nawczych, najczęściej opatrzone tytułem albo nazwą, numerem i przynajmniej rokiem wydania, a w szczególności: dzienniki i czasopisma, serwisy agencyjne, stałe przekazy teleksowe, biuletyny, programy radiowe i telewizyjne oraz kroniki filmowe; wszelkie istniejące i powstające w wyniku postępu technicznego środki masowego przekazywania, w tym także rozgłośnie oraz tele- i radiowęzły zakładowe, upowszechniające publikacje periodyczne za pomocą druku, wizji, fonii lub innej techniki rozpowszechniania; prasa obejmuje również zespoły ludzi i poszczególne osoby zajmujące się działalnością dziennikarską"2. Swoim zasięgiem definicja ta obejmowałaby całe podziemne media, również agencje, wydawnictwa, podziemne radio i zespoły redakcyjne. Osobiście jestem jednak przeciwnikiem tak szerokiego rozumienia słowa prasa i uwzględnianiu tego $\mathrm{w}$ definicji prasy drugiego obiegu. Druga definicja odnosiłaby się zatem raczej do całości zjawiska zwanego media podziemne czy opozycyjne.

$\mathrm{Z}$ badaniem prasy drugiego obiegu wiążą się liczne problemy. Poszczególne wydania prasowe tworzą czasem zamkniętą i jednorodną całość. Jak wiadomo, wśród tytułów prasy niezależnej sporo było wydawnictw efemerycznych, które znikały po jednym czy kilku numerach, ale były wydawane z zamiarem utrzymania periodyczności. Definicja ustawowa wskazuje, że prasa powinna się ukazywać nie rzadziej niż raz do roku, wyróżniać się stałym tytułem i kolejnym numerem. $\mathrm{W}$ przypadku prasy drugiego obiegu bywało różnie. Często tytuły ukazywały się z przerwa, były wielokrotnie wznawiane, modyfikowały czy zmieniały tytuł, myliły, gubiły bądź nie zachowywały numeracji. Wszystko to wynikało z trudnych warunków nielegalnej działalności w państwie komunistycznym. Dlatego w definicji drugiego obiegu kładę nacisk na sam zamiar wydawania periodycznego, nie rzadziej niż raz do roku, zamiar tytułowania i poprawnego numerowania, zdając sobie jednakowoż sprawę z niekonsekwencji samego drugiego obiegu. Zadaniem badacza jest próba ustalenia, dlaczego zamiar wydawania się nie powiódł, pomylono numerację albo czasowo zawieszono druk, dlaczego kilka razy zmieniano tytuł?

Drugi problem to digitalizacja źródeł drugiego obiegu. Mamy w Polsce kilka ośrodków digitalizujących bibułę. Zdarza się, że kilka z nich robi coś równocześnie, pozyskuje granty na podobne cele, nie ma jednej, centralnej instytucji, która by za to odpowiadała, koordynowała działania. Nie ma nowoczesnych standardów digitalizacji zbiorów. Ich jakość pozostawia często wiele do życzenia i nie sposób ich czytać czy komfortowo przeglądać.

Trzeci problem to brak zidentyfikowanego, zintegrowanego środowiska badaczy prasy podziemnej. Ważną inicjatywą mającą integrować badaczy m.in. wokół problematyki prasy podziemnej są cykliczne konferencje pod nazwą „Czas bibuły”, organizowane przez dr. Romana Wróblewskiego z Instytutu Dziennikarstwa

${ }^{2}$ Ustawa z dnia 26 stycznia 1984 r. Prawo prasowe, tekst ujednolicony, rozdz. 1, Art. 7.1. W tej definicji fragment: „zajmujące się działalnością dziennikarską” warto byłoby zastapić innym fragmentem z ustawy: „zajmujące się przygotowaniem do wydania materiału prasowego”, zdecydowanie lepiej oddającym charakter pracy podziemnych wydawców i osób przygotowujących teksty. 
i Komunikacji Społecznej Uniwersytetu Wrocławskiego. We wrześniu 2016 roku odbyła się piąta edycja. W czerwcu 2017 planowana jest międzynarodowa konferencja naukowa „Od Zapisu do... zapisu historii. Kultura poza cenzurą w Europie Środkowej i Wschodniej w latach 1977-1991" mająca ogniskować środowisko badaczy podziemnego ruchu wydawniczego z Europy Środkowej i Wschodniej.

Należy też zaznaczyć, że brakuje ściślejszej współpracy między badaczami prasy drugiego obiegu, a instytucjami digitalizującymi i opracowującymi bibliograficznie zbiory.

Problem czwarty to nie tylko atomizacja środowiska badaczy, ale i anonimizacja procesu przygotowywania i wydawania prasy drugiego obiegu, co znacznie utrudnia identyfikację oraz analizowanie tytułów, które często są jedynymi dowodami istnienia poszczególnych środowisk opozycyjnych. Anonimowość rodzi problem praw autorskich. Drugi obieg był przykładem i respektowania, i ignorowania praw autorskich. W jego prasie bardzo często znajdujemy formułę, że coś jest „wydane bez wiedzy i zgody autora”, a tymczasem było wydane za jego wiedzą i zgoda. Obecnie mylnie jest to interpretowane jako przykład łamania praw autorskich. Tymczasem formuła „bez wiedzy i zgody autora”, za pomocą której redakcja oficjalnie odcinała się od autora, miała go w rzeczywistości chronić przed represjami ze strony aparatu władzy. Podobnie jest z publikowaniem tekstów autorów zagranicznych. Wielu czuło dumę, że znalazło się w prasie podziemnej, choć żadnych „kwitów” i stosownych zgód nikt wtedy nie zbierał. Jest oczywiście i druga strona medalu. Tłumaczono i przedrukowywano teksty z prasy zagranicznej rzeczywiście bez wiedzy i zgody autora, thumaczono i drukowano książki ,po piracku”, na zdobywanym nielegalnie papierze. Nie powinno nas to jednak paraliżować przed publikowaniem źródeł drugiego obiegu w przestrzeni publicznej.

Piąta kwestia: $w$ artykułach zamieszczonych w prasie podziemnej mamy problem z tzw. gęstością tekstów, zarówno jakościowa, jak i ilościową. Ze względu na ograniczoną ilość miejsca, spowodowaną działaniem w warunkach konspiracji, materiały prasowe są nasycone faktami, tematami, motywami, interpretacjami, sensami, to wszystko się ze sobą miesza, nakłada. Zdarzają się zbyt długie i rozbudowane zdania, pojęcia i słownictwo nieraz dotyczy bardzo specjalistycznych kwestii związanych z historia, zakładami pracy, sytuacją w aparacie władzy czy represjami. Teksty są również bardzo ciasno rozmieszczone na stronie (maksymalnie upchnięte). Nie ma miejsca na wyjaśnianie kontekstów, tła ówczesnej epoki, brakuje wprowadzeń do tematu. Czytanie bibuły jest trudnym i żmudnym zadaniem, zniechęcającym wielu potencjalnych badaczy. Przeczytanie jednej strony prasy podziemnej w formacie A4 to jak przeczytanie kilku stron prasy współczesnej. Na potrzeby niniejszych rozważań wpisałem trzy próbki tekstu z prasy drugiego obiegu do specjalnej aplikacji na stronie jasnopis.pl, by zmierzyć zrozumiałość tekstu (m.in. na podstawie wzoru Walerego Pisarka). Wyniki nie są zaskakujące - uzyskujemy klasę nieco trudniejszego tekstu (dla ludzi ze średnim 
wykształceniem lub z dużym doświadczeniem życiowym) lub klasę tekstu jeszcze trudniejszego (przeznaczonego dla ludzi wykształconych).

Szósty problem wiąże się z faktem, że tradycyjne narzędzia przy badaniu drugiego obiegu zawodza. Trudno stosować wyłącznie analizę zawartości ograniczającą się do samej treści informacji, a nie służącą opisywaniu ukrytych intencji i reakcji na treść (Berelson) zgodnie z warunkiem obiektywności, systematyczności i ujęciem ilościowym (Pisarek 1983, s. 30). W przypadku drugiego obiegu praktycznie niemożliwe jest ograniczanie się do jawnej zawartości przekazów. Gdy tekst dotyczy jakiegoś tematu, to w tle jest walka z komuną, walka o autonomię uczelni, walka o uwolnienie więźniów politycznych. Wszędzie jest walka o coś, akcyjność. Intencją drugiego obiegu jest zaszczepianie niezgody na to, co się dzieje wokół nas, zmienianie rzeczywistości komunistycznej, wywoływanie społecznych reakcji (np. zgromadzenie się na manifestacji). Na drugim planie jest ograniczona bądź odebrana wolność. Czytanie tekstów prasy podziemnej bez uwzględniania złożonej sytuacji, w jakiej się ta prasa ukazywała, może prowadzić do wielu nieporozumień. Ale i tu powstaje kolejny problem. Jeśli uznamy współczesną rozszerzoną definicję analizy zawartości prasy (obejmującą również treść) jako zespół

różnych technik systematycznego badania strumieni lub zbiorów przekazów, polegającego na możliwie obiektywnym (w praktyce zwykle: intersubiektywnie zgodnym) wyróżnianiu i identyfikowaniu ich możliwie jednoznacznie skonkretyzowanych, formalnych lub treściowych elementów oraz na możliwie precyzyjnym (w praktyce: ilościowym) szacowaniu rozkładu występowania tych elementów i na głównie porównawczym wnioskowaniu, a zmierzającego przez poznanie zawartości przekazów do poznania innych elementów i uwarunkowań procesu komunikacyjnego (Pisarek 1983, s. 45),

to $\mathrm{i}$ tak mamy problem $\mathrm{z}$ jednoznacznością, konkretnością i precyzyjnością; $\mathrm{z}$ opisaniem $\mathrm{w}$ ten sposób strumieni komunikacyjnych, przejawów zachowań, motywacji ludzkich i socjologicznym ujęciu autorów i skutków ich działalności. $\mathrm{Na}$ to nakłada się problem z zastosowaniem formuły Harolda Lasswella - też w wariantach Mieczysława Kafla (1969, s. 39 i 122-127) i Pawła Dubiela (1969, s. 9-112). W drugim obiegu jedno jest pewne: wiemy, co bezpośrednio, dosłownie mówi. Dowodem jest zapisany bądź zadrukowany kawałek papieru. Ale często nie wiemy, jakie jest ukryte dno wypowiedzi, kto mówi, jakim kanałem, do kogo i z jakim skutkiem. Ale jeśli już nawet uda się nam ustalić, kto mówi, to mamy problem z ustaleniem kanałów komunikacyjnych (czyli kolportażowych). Najtrudniejsze i chyba niemożliwe w pełni do ustalenia są skutki i zasięg oddziaływania drugiego obiegu. Najnowsze badania przeprowadzone na zlecenie Stowarzyszenia Wolnego Słowa są nieco zaskakujące. Pokazują,

że co czwarty Polak miał w stanie wojennym kontakt $\mathrm{z}$ podziemnymi wydawnictwami. W miastach powyżej 200 tysięcy bibułę czytywał co drugi, a w ponadpółmilionowych metropoliach -60 procent mieszkańców (Bibuła 4, s. 22). 
Dawid Warszawski podał, że według ocen ośrodka prasoznawczego w Krakowie prasa podziemna oddziałuje na 3,5 mln ludzi (włącznie z tymi, do których dociera coś sporadycznie) i twierdził, że przeszacowano tę liczbę. Sam oceniał zasięg oddziaływań na około $1,5-2 \mathrm{mln}^{3}$.

Problemy stwarza także analiza zawartości np. metodą mierzenia stopnia uwidocznienia Jacques'a Kaysera. Rozkład treści w drugim obiegu często nie był determinowany założeniami wizualnymi czy marketingowymi, lecz chęcią umieszczenia jak największej ilości materiałów na jak najmniejszej powierzchni. Oczywiście są tytuły, przy badaniu których ta metoda się sprawdzi (zwłaszcza wysokonakładowe tygodniki, np. Tygodnik Mazowsze), gorzej z mniejszymi gazetami, nie mówiąc o tych zadrukowanych bardzo gęsto.

$\mathrm{Na}$ koniec warto wspomnieć o kłopotach ze zbudowaniem klucza kategoryzacyjnego dla badania wypowiedzi prasowych z drugiego obiegu - wobec ich niejednoznaczności, wielopoziomowości interpretacyjnej i kontekstowej, braku logiczności formy przekazu wynikającej z konspiracyjnych warunków przygotowywania materiałów, w których de facto trzeba szukać uzasadnień dla jej bra$\mathrm{ku}$. W badaniach nad drugim obiegiem pojawia się również problem stosowania tzw. metody reprezentatywnej i doboru próbki badawczej. Z moich doświadczeń wynika, że próba powinna być maksymalnie szeroka. Ostatnio przygotowywałem tekst o muzyce w PRL w prasie drugiego obiegu ukazującej się w Gdańsku. Gdybym obejrzał 10 wybranych losowo tytułów i z każdego wybrał losowo po 5 numerów, o muzyce zapewne nie znalazłbym nic. Stwierdziłbym wówczas, że drugi obieg na Pomorzu nie poruszał tej problematyki wcale. A tak nie jest.

\section{Postulaty badawcze}

Podczas wspomnianych wyżej badań po przejrzeniu blisko 1400 numerów 29 pism znalazłem 34 teksty dotyczące muzyki i wielu innych ciekawych zagadnień związanych z tą tematyką. Powstał na ten temat kilkunastostronicowy tekst. Gdybym poprzestał na ograniczonej liczbie tekstów, nie powstałoby nic. Stąd podkreślam konieczność pobierania możliwie dużych prób badawczych (tzw. badania przesiewowe). Drugi obieg jest bardzo różnorodny, zaskakujący, niepoddający się racjonalności socjologicznej i tradycyjnym metodom badań. Coś się nagle pojawia i nagle znika. Dlatego tradycyjne podziały, tematy, kategorie czy gatunki dziennikarskie w prasie drugiego obiegu się mieszają i nakładają. $Z$ jednej strony zawiera ona sporo powtarzalnych, a z drugiej - unikalnych treści tematycznych.

Powstaje pytanie, czy należałoby pomyśleć o stworzeniu klucza kategoryzacyjnego specjalnie dla drugiego obiegu? Skoro zamówienia publiczne udało się opisać za pomocą kodów CPV i każda rzecz, jaka powstała na tym świecie, jest

${ }^{3}$ Zob. „Drugi Obieg” - plusy i minusy. Z Dawidem Warszawskim rozmawia Krzysztof Czabański. Kultura 1989, nr 6/501, s. 85. 
tak opisana, to może jednak byłoby to możliwe, jak postulowała to w latach 60 . Irena Tetelowska? Na pewno tworzenie kluczy kategoryzacyjnych jest możliwe w odniesieniu do jednego czasopisma czy określonych kategorii tematycznych, problemowych w badaniach przekrojowych pism drugiego obiegu. Tym posługuję się na co dzień. Zdecydowanie opowiadam się również w badaniu wypowiedzi prasowej za metodą ilościowej analizy treści prasy, a w szczególności za metodą badania jej powierzchni - stosując jako jednostkę stronę/kolumnę (lub jej części). Pozwala ona ujmować treść w zestawienia statystyczne, co stanowi świetny punkt wyjścia do dalszych badań. Często same zestawienia zaskakują i pozwalają dostrzegać związki, wnioskować, stawiać hipotezy, weryfikować obiegowe opinie.

Ważnym postulatem badawczym jest konieczność wyznaczenia nowych standardów digitalizacji drugiego obiegu. W myśl przysłowia „każdy sobie rzepkę skrobie" zbiory te są zdigitalizowane częściowo w Bibliotece Narodowej, Ośrodku KARTA, Europejskim Centrum Solidarności, Bibliotece Uniwersytetu Gdańskiego, Archiwum Komisji Krajowej NSZZ „Solidarność” i innych ośrodkach. Konieczna jest koordynacja działan digitalizacyjnych, współpraca w tym zakresie poszczególnych instytucji archiwizujących. Zbiory zdigitalizowane w poszczególnych ośrodkach są różnej jakości, często utrudniającej bądź uniemożliwiającej badania naukowe. Praktycznie żaden ze zeskanowanych materiałów nie został przetworzony do postaci edytowalnej (nie został poddany technice OCR - Optical Character Recognition), co zdecydowanie obniża ich wartość. Nie jest to materiał badawczy, który umożliwia wyszukiwanie treści historycznych, osób, haseł, badanych zagadnień, zdecydowanie ułatwia proces badawczy i zachęca kolejnych badaczy do podjęcia badań nad drugim obiegiem. Niestety, część skanów w aktualnej postaci nie nadaje się do poddania ich technice OCR, co w praktyce oznacza konieczność ponownej digitalizacji materiałów.

Dotychczas nikt nie podjął się wyznaczenia nowoczesnych standardów digitalizacji zbiorów drugiego obiegu. Kierując się swymi dotychczasowymi doświadczeniami badawczymi, postulowałbym określenie docelowej jakości skanów JPEG czy TIFF, które nadawałyby się do poddania ich technice OCR. Po drugie, stosowne eksperymenty i wzmocnienie oprogramowania OCR umożliwiłyby przetworzenie części zbiorów do postaci edytowalnej. Po trzecie, materiał drugiego obiegu powinien zostać zdigitalizowany w czterech najpopularniejszych formatach: PDF, DjVu, ePub, MOBI. W związku z tym pojawia się pewien problem, który wymaga wyjaśnienia. Obecnie oprogramowanie dLibra, pod którym zamieszczane są digitalizowane zbiory w polskich bibliotekach cyfrowych, umożliwia zapisanie obiektu cyfrowego z wykorzystaniem jednego formatu prezentacyjnego. Oznacza to, że redaktorzy biblioteki cyfrowej muszą zdecydować, w którym formacie (i tylko w tym) dany obiekt będzie dostępny dla użytkowników. Z praktyki wynika, że niektóre formaty prezentacyjne są bardzo dobre do zastosowania przez profesjonalistów, natomiast trudne do odczytania przez użytkowników bibliotek cyfrowych. Przykładem może być format DjVu, który ma bardzo dobre parametry techniczne w zakresie kompresji, wielowarstwowo- 
ści czy przesyłu danych przez Internet. $\mathrm{Z}$ wymienionych względów format $\mathrm{Dj} V \mathrm{U}$ zyskał dużą popularność wśród polskich bibliotek cyfrowych i osób profesjonalnie zajmujących się eksploracją danych z bibliotek cyfrowych (np. naukowców humanistów). $\mathrm{Z}$ biegiem czasu okazało się jednak, że format $\mathrm{Dj} \mathrm{Vu}$, choć nadal posiada bardzo dobre parametry techniczne, jest trudny do wyświetlenia przez typowego użytkownika Internetu. Wynika to przede wszystkim z faktu niedostatecznego wsparcia tego formatu przez przeglądarki internetowe czy wtyczki do poszczególnych przeglądarek. Sytuacja jest jeszcze trudniejsza w przypadku urządzeń mobilnych, bo niekiedy (np. w urządzeniach korzystających z systemu operacyjnego iOS) przeglądanie plików $\mathrm{Dj} V u$ jest w praktyce niemożliwe. Na całym świecie odchodzi się już od tego formatu. Należy więc wyznaczyć nowe standardy prezentacji zbiorów. W tym celu powinna zostać przygotowana w systemie dLibra funkcja wieloformatowości, wprowadzająca możliwość podłączania kilku formatów prezentacyjnych do jednego obiektu cyfrowego. Umożliwi to przełamanie obecnych barier i otwarcie zupełnie nowych perspektyw rozwoju polskich bibliotek cyfrowych. Redaktor biblioteki cyfrowej będzie mógł przygotować kilka formatów prezentacyjnych, które wprowadzi do jednego obiektu. Dzięki temu użytkownicy będą w stanie w łatwy sposób przeglądać obiekty w zaawansowanym oprogramowaniu (np. wtyczka $\mathrm{Dj} V u$ ), na tablecie (np. galeria zdjęć lub plik PDF) oraz na czytnikach e-book (np. format MOBI lub ePub) ${ }^{4}$. Funkcja ta zrewolucjonizuje cały proces digitalizacji i prezentacji zbiorów w Polsce (nie tylko drugiego obiegu) oraz umożliwi korzystanie z dokumentów drugoobiegowych w popularnych formatach (PDF, ePub, MOBI) na urządzeniach przenośnych w każdym miejscu na świecie. Wzory takich rozwiązań znajdują się na stronie https://openlibrary.org/, z której w ciagu miesiąca korzysta ponad 4 miliony użytkowników. Zmiana ta mogłaby w znaczący sposób zachęcić uczniów, studentów, nauczycieli oraz kadrę naukową (w tym młodych naukowców korzystających w dużo większym stopniu z urządzeń mobilnych) do czerpania w pracy badawczej ze źródeł drugiego obiegu. Taka digitalizacja umożliwiłaby eksport drugiego obiegu za granicę. Umieszczenie np. kolekcji gdańskiego drugiego obiegu w ramach zasobów Pomorskiej Biblioteki Cyfrowej, a tym samym w Federacji Bibliotek Cyfrowych, a przez nią w Europeanie, czyli bibliotece i archiwum cyfrowym, skutkowałoby dostępnością prasy drugiego obiegu w sieci europejskiej. Warto również postulować cyfrowe publikowanie materiałów na wolnych licencjach CC 3.0, w najpopularniejszych repozytoriach i bibliotekach internetowych Polski i zagranicy po to, by w sposób bezpłatny udostępnić je jak najszerszej grupie odbiorców oraz promować ich wykorzystanie do celów naukowo-edukacyjnych. Należałoby przeznaczyć jakąś kwotę na wykup praw autorskich, zwłaszcza do książek wydawanych nielegalnie w drugim obiegu. Tu

\footnotetext{
${ }^{4}$ Korzystam tu z materiałów przygotowanych w 2014 r. przez Tomasza Parkołę z Poznańskiego Centrum Superkomputerowo-Sieciowego na potrzeby projektu naukowego „Drugi obiegi w Trójmieście w latach 1976-1989".
} 
zapewne potrzebne byłyby specjalne projekty naukowe lub rozwiązania na poziomie ustawowym. Może warto rozważyć na gruncie polskim wyłączenie prasy (też książek) drugiego obiegu ze ścisłych rygorów prawa autorskiego, tak by móc je zamieszczać bez konsekwencji prawnych w repozytoriach cyfrowych. Wydaje się zasadne, aby państwo wzięło odpowiedzialność za ewentualne roszczenia autorskie wobec podziemnych wydawców czy obecnie digitalizujących i prezentujących zbiory w bibliotekach cyfrowych.

Poddanie drugiego obiegu OCR otworzyłoby zupełnie dotąd nieznane perspektywy badawcze. Zwłaszcza w dziedzinie analiz problemowo-tematycznych, szukania informacji o osobach, wydarzeniach, symbolach, ważnych pojęciach. Uzyskując narzędzie badania komunikacji prasy drugiego obiegu, możemy dokonywać szerokich badań lingwistycznych, np. trudności języka tekstu (jego dostosowania do poszczególnych grup społecznych czy środowisk), a przez analizę słów, zastosowanych pojęć, szukanie powiązań językowo-słownych etc. znakomicie badać język opozycji, budować klucze kategoryzacyjne. Bez OCR, specjalistycznych programów do wyszukiwania i analizowania języka, będziemy zmuszeni (jak dziś) do ręcznego wertowania setek numerów prasy drugoobiegowej. Warto zaznaczyć, że profesjonalnie wykonany OCR jest skuteczniejszy od człowieka. Co ważne, znika też konieczność wykonywania gigantycznych bibliografii zawartości. Wyszukiwanie pełnotekstowe w zupełności wystarcza.

Kolejnym fundamentalnym zagadnieniem jest nieustanne doskonalenie warsztatu z zakresu oral history. Jednym z podstawowych elementów pracy badacza zajmującego się historią najnowszą jest wywoływanie notacji dźwiękowych bądź filmowych. W przypadku badania prasy drugiego obiegu notacje można definiować jako wywiady z osobami uczestniczącymi w działaniach opozycji demokratycznej czy Solidarności i tworzącymi niezależny ruch wydawniczy czy kulturę niezależną ${ }^{5}$. Notacje są jedną z interdyscyplinarnych form poznawania przeszłości, które pozwalają na wykorzystanie pamięci indywidualnej do konstruowania pamięci i tożsamości zbiorowej:

Stać się może (oral history) uzupełnieniem i zilustrowaniem historii oficjalnej, pozostać w opozycji do niej lub wpłynąć na zmianę charakteru nauki historycznej. Pozwoli nam ona odkrywać nieznane dotąd fakty i zjawiska, umieszczać te już zbadane w nowych kontekstach czy przypisywać im nowe znaczenia (Nowak 2011).

Notacje mają bardzo duże znaczenie dla dokumentowania działalności podziemnych wydawców czy redaktorów. Podstawowym zadaniem badacza jest bardzo precyzyjne przygotowanie się do rozmowy (w tym opracowanie kwestionariusza), a następnie nieustanne dopytywanie, drążenie rozmówcy, podważanie jego wypowiedzi, konfrontacja $\mathrm{z}$ tym, co zostało zapisane w prasie drugoobiegowej i materiałach archiwalnych. Ale najczęściej wobec braku tych źródeł (poza wytworzonymi przez rozmówcę gazetami, książkami) notacje stanowią unikalne

${ }^{5}$ Więcej o projekcie notacji filmowych: [http://www.ecs.gda.pl/title,Notacje_filmowe,pid,389. html]. 
i jedyne źródło wiedzy o formach podziemnej działalności wydawniczej. Stają się wówczas źródłem historycznym o fundamentalnym znaczeniu.

Istnieją różne rodzaje notacji, np. dźwiękowe i filmowe. Każda z tych dwóch ma swoje wady i zalety. W notacji dźwiękowej rozmówca bardzo często zapomina o tym, że jest nagrywany i wywiad przeradza się we wspólną wędrówkę w przeszłość, pozwala na odkrywanie wspomnień, co byłoby niemożliwe przed okiem kamery. Notacja filmowa nadaje spotkaniu ton oficjalny, często blokuje czy „usztywnia” rozmówcę. Brak intymności spotkania obniża jakość wspomnień. $Z$ drugiej strony w oku kamery widzimy sylwetkę naszego bohatera, zostają zapisane gesty, mimika, emocje, które często powodują zmianę znaczenia wypowiedzi, dają jej pełniejszy obraz. Nawet najdoskonalsza transkrypcja tekstu nie jest w stanie oddać emocji nagrania. Ponadto notacja filmowa może się stać częścią filmu, np. dokumentalnego, który z notacji indywidualnej czyni element tożsamości zbiorowej czy wspólnej pamięci historycznej.

Na uwagę zasługują notacje pełne - biograficzne i tematyczne. Biograficzny charakter relacji polega na rejestrowaniu, w miarę możliwości, pełnej drogi życiowej rozmówców; (re)konstruują oni w opowiadaniu swoją biografię i umieszczają w nim - jako jedne z wielu - te jej fragmenty, które dla nich/dla nas są szczególnie ważne. Biograficzne notacje pozwalają zatem wskazać na motywy działalności podziemnych wydawców, korzenie, które zadecydowały o podjęciu przez nich oporu, drogę dojścia do uczestnictwa w „papierowej rewolucji”. Postulat nagrywania całościowych notacji wydaje się wysoce uzasadniony. Notacja biograficzna, jak najbardziej wyczerpująca, nieraz wielogodzinna, pozwala jednak, wspólnie, krok po kroku przejść życie naszego rozmówcy i otworzyć uśpione pokłady pamięci, budować związki przyczynowo-skutkowe i narrację o wydarzeniach. Czasem spotkanie ma charakter terapeutyczny i staje się spowiedzią życia pytanego. W trakcie rozmowy pojawiają się kolejne wątki i dygresje. $Z$ jednej strony to niebezpieczne - umyka podstawowy temat spotkania, jeśli taki mamy. $Z$ drugiej jednak możemy ustalić ważne fakty czy usłyszeć cenne komentarze/interpretacje historii najnowszej, niezapisane dotąd w podręcznikach czy literaturze. Takie notacje pozwalają kolejnym badaczom stawiać nowe pytania, weryfikować dotychczasowe ustalenia (Filipkowski 2005, s. 22).

Ostatnio modna staje się na powrót metoda wywiadu - notacji etnograficznej, która z pozoru przybiera charakter luźnej czy przypadkowej rozmowy i staje się pretekstem do uzyskania informacji potrzebnych badaczowi. Badania terenowe prowadzone tą metodą zakładają nie tylko rozmowy w zaciszu domowym, ale także wspólne spacery, np. w miejsca, w których odbywał się druk, spotkania redakcyjne i znajdowały się punkty kolportażowe. Obecność w historycznych miejscach uaktywnia pokłady wspomnień i wydobywa na nowo dawne wydarzenia, nigdzie dotąd niezapisane i nieopracowane. Ponownie pozostaje dylemat, jak nagrywać takie spotkania. Czasem wypadają one lepiej bez użycia kamery, która niejako krępuje lub nawet paraliżuje rozmówcę i odbiera intymny charakter wywiadu. Najlepszy okazuje się wówczas ukryty smartfon, niekrępujący rozmówcy 
(mimo iż rozmówca wyraził zgodę na nagrywanie). Z mojego doświadczenia wynika jednak, że warto zaryzykować filmowanie takich spotkań. W takich wypadkach kamera wręcz ośmiela, podziemny redaktor czy drukarz chcą się pochwalić tajną drukarnią, lokalem konspiracyjnym, czują dumę ze swojej działalności i mają satysfakcję, że miejsce to np. nigdy nie zostało odkryte przez komunistyczne władze. Również i te materiały znakomicie można wykorzystać przy realizacji filmów dokumentalnych czy edukacyjnych.

Wszystkie notacje można także spisywać lub poddać bardzo szczegółowej transkrypcji, co da (podobnie jak w przypadku OCR) możliwość wyszukiwania pełnotekstowego. Istnieją także (niestety bardzo drogie, lecz niedoskonałe) programy komputerowe umożliwiające wyszukiwanie informacji bezpośrednio w nagraniach. Odpada wówczas konieczność spisywania wywiadów.

\section{Model badawczy-podejście holistyczne}

Chciałbym zaproponować holistyczne podejście do analiz drugiego obiegu, wynikające z moich wieloletnich doświadczeń badawczych dotyczących tej problematyki. Na początku rysują się dwie drogi. Pierwszą nazwałbym archeologią historyczną. Naszym celem jest kronikarski zapis, jak było, odtworzenie procesu powstania i funkcjonowania danego tytułu prasowego wraz ze szczegółową analizą treści/zawartości. Pojawia się tu problem z postawieniem tez czy hipotez badawczych, bo często ich nie ma. Tworzymy coś na podstawie odkrywania i odczytywania podziemnych znaków i znaczeń. Hipotezy czy tezy formułujemy w trakcie. Drugą drogą są badania porównawcze poszczególnych tytułów celem opisania, wyjaśnienia interesującego nas zagadnienia, np. Katynia, Czarnobyla, Afganistanu, muzyki, teatru, zakładów pracy (np. Stoczni Gdańskiej) etc. $\mathrm{W}$ drugim obiegu można znaleźć ogrom informacji na wiele tematów. Wówczas możemy stawiać tezy i hipotezy: np.: „drugi obieg rzetelnie opisywał katastrofę w Czarnobylu” albo „ilość problematyki muzycznej i jej charakter potwierdza tezę o polityczności drugiego obiegu”, ,Grudzień '70 ważnym symbolem mobilizacji społecznej" etc. W obu wypadkach ważna będzie próba określenia roli i znaczenia pisma/publicystyki, zasięgu jego oddziaływania. W każdym przypadku mamy do czynienia z dwoma typami badań. Jakościowe dotyczą strony ideowej, literackiej, typologicznej pism, myśli publicystycznej, politycznej, poziomu informacyjnego, stylu dziennikarskiego, typów pism etc. Ilościowe z kolei mają za zadanie określić zakres miejsca poświęcanego pewnej strukturze tematycznej lub rodzajowej (układ i proporcje liczbowe elementów treści). W ujęciu holistycznym dokonujemy badań jakościowych i ilościowych równolegle.

Ale po kolei: załóżmy, że znaleźliśmy tytuł prasy drugiego obiegu nigdzie i nigdy dotąd niezbadany. Jeśli mamy możliwości, staramy się o jego profesjonalną digitalizację, zachęcamy istniejące instytucje do opracowania jego wersji cyfrowej. Następnie analizujemy dostępną literaturę przedmiotu, istniejące notacje 
czy relacje oraz znane i publikowane archiwalia. Jest to swoista „rozbiegówka” do tematu. Celem jest maksymalnie pełne ustalenie aktualnego stanu wiedzy na temat przedmiotu naszych badań. Często uzyskujemy niewiele lub nic.

Ponieważ, przystępując do badań nad drugim obiegiem, ogólnie znamy jego treści, należy zacząć od gruntownej analizy prasy. Z jednej strony należy się przede wszystkim skupić na jej treści, ale też i zawartości, czyli m.in. formie, w jakiej ta prasa się wypowiada. Możemy określić proporcje poszczególnych wypowiedzi i zakresy tematyczne, a więc zbudować na potrzeby badania klucz kategoryzacyjny. Do każdego tematu - klucza (lub np. gatunku, autora) przyporządkowujemy wybrane teksty. Następnie mierzymy powierzchnię poszczególnych tekstów poświęconych danemu tematowi, np. za pomocą liczby stron czy w $\mathrm{cm}^{2}$. Wykonujemy zestawienia statystyczne służące jako punkt wyjścia do merytorycznej analizy prasy drugiego obiegu.

O ile kategorie klucza można sztywno określić i nie przenikają się one tematycznie, są rozłączne i wyczerpujące, dostosowane do badanego materiału, to mamy problem z jednoznacznym przyporządkowaniem poszczególnych tekstów do jednej kategorii tematycznej czy gatunkowej (gatunki w drugim obiegu to temat na osobne opracowanie). Przykładowo, w tekście o strajku w 1988 roku są również zawarte tematy okragłego stołu, Lecha Wałęsy czy sierpnia 1980, a gatunki się mieszają. W teorii należałoby tekst podzielić i przyporządkować jego składowe do poszczególnych kategorii: strajki 1988, Okrągły Stół, sierpień 1980, Lech Wałęsa. Można też prześledzić, kiedy tekst ma charakter informacyjny, reportażowy, kiedy staje się wywiadem i nagle felietonem. W praktyce do końca nie jest to możliwe i przyporządkowuje się go do ewidentnie dominującej kategorii tematycznej, w tym przypadku ,strajki 1988”. Pojawia się problem, jeżeli nie da się wyodrębnić takiej dominanty tematycznej. Należy wtedy próbować wydzielić $z$ tekstu konkretne fragmenty i przyporządkować je do innych kategorii tematycznych.

W kontekście drugiego obiegu ciekawy wydaje się postulat budowania kategorii krzyżowych. Ostateczny trud przyporządkowania poszczególnych tekstów do kategorii tematycznych się opłaca. Po wpisaniu danych do Excela otrzymujemy wykresy dotyczące powierzchni poświęconej poszczególnym tematom, jakie występują w piśmie, liczby tekstów publikowanych przez poszczególnych autorów czy udziału poszczególnych gatunków. Zestawienia w Excelu stanowią doskonały punkt wyjścia do opisania samej treści, pokazują pola zainteresowania pism, najważniejszych publicystów. Można dokonywać pomiarów z rozróżnieniem na okresy - tygodnie, miesiące czy lata - i na podstawie tego wnioskować o ewolucji tytułów.

Opisane wyżej czynności kategoryzacyjne nazwałbym pierwszym etapem rozmowy z „bibułą". Drugim etapem jest poszukiwanie informacji na temat środowiska lub osób, które stały za wydawaniem pisma. W badanej prasie znajdujemy informacje na temat genezy tytułu, apele o przekazywanie papieru, funduszy, sprzętu drukarskiego. Możemy zrobić listę inicjałów, pseudonimów, autorów. 
Staramy się je wstępnie rozszyfrować, posługując się słownikiem pseudonimów (Swierczyńska 1995), który niestety w wielu przypadkach nie wystarcza. Pojawiają się teksty na temat samego środowiska, jego koncepcji, metod i zasięgu działania, artykuły programowe. Czasem uwidaczniają się konflikty, spory, dyskusje programowe. Obserwujemy zmiany graficzne, cenowe, ewolucje tematyczną $\mathrm{i}$ wiele innych zagadnień. Rozmowa badacza z prasą staję się przygotowaniem do rozmowy z jej twórcami, autorami. Badacz staje się pośrednikiem w dialogu między prasą a jej twórcą. Wobec zjawiska ochrony danych osobowych, likwidacji książek telefonicznych i ponownej anonimizacji/atomizacji społecznej (co jest ciekawe w kontekście drugiego obiegu) jesteśmy skazani na indywidualne poszukiwania redaktorów czy podziemnych drukarzy. Czasem przypomina to „dziennikarstwo śledcze". Na szczęście badania historyczne spowodowały, że sporo już wiemy, a przynajmniej istnieją jakieś punkty zaczepienia. Pomocą służą instytucje państwowe, rodzina, znajomi, inni badacze, a obecnie również Facebook. Sporo osób z drugiego obiegu weszło w obieg publiczny, co ułatwia, ale i zarazem utrudnia nawiązanie kontaktu. Przy analizie pism drugiego obiegu najważniejsze są dwie osoby: redaktor naczelny/dyżurny (choć formalnie zazwyczaj nikogo takiego nie było, mowa o liderze, autorytecie środowiska uznawanym za naczelnego) oraz osoba, która w największym stopniu odpowiadała za druk pisma lub jego organizację. Kiedy uda się dotrzeć do jednego, otwierają się kolejne drzwi. Bardzo często uruchamia się lawina $\mathrm{i}$ jesteśmy w stanie nawiązać kontakt $\mathrm{z}$ kilkoma czy kilkunastoma osobami, dokonać pełnej identyfikacji redakcji, grona autorskiego, kolejnych członków redakcji, drukarzy i lokali podziemnych. Zwłaszcza cenni są kolporterzy pisma, mogący coś powiedzieć o jego oddziaływaniu.

Następuje kolejna faza badań - uzyskanie notacji biograficznych albo skupionych na pewnych wątkach czy też etnograficznych. Wartościowe są rozmowy w miejscach, w których były przygotowywane wydawnictwa, wizje lokalne w podziemnych drukarniach. Jak wspomniano wyżej, miejsca i spotkania należałoby koniecznie utrwalić na profesjonalnej taśmie filmowej, przynajmniej w jakości Full $H D$, z udziałem profesjonalnego operatora. Materiał mógłby być wówczas wykorzystywany, np. na potrzeby produkcji filmów dokumentalnych. Wobec braku środków finansowych często jednak pozostaje nagranie na smartfonie.

Kluczem do sukcesu w rozmowie jest przygotowanie bardzo szczegółowego i rozbudowanego kwestionariusza. Do standardowych zaliczyć można pytania o to, jak radzono sobie z drukiem, zdobywaniem papieru, farb, sprzętu drukarskiego, części zamiennych, skąd czerpano środki finansowe, czy był jakiś system wynagrodzeń, jak wyglądał system kolportażu. Pytamy również o zawartość dlaczego taka, a nie inna, skąd zainteresowanie poszczególnymi tematami, wątkami, zaglądamy wspólnie do pisma. Pozwala to naszemu rozmówcy uaktywnić wspomnienia - pewne wątki powracają, przypominają się. Mamy możliwość dopytania o niezrozumiałe dla nas wypowiedzi prasowe. Drugiego dna, intencji, aluzji piszących często nie odkryjemy bez rozmowy z samymi twórcami pisma. Możemy się jedynie domyślać pewnych spraw, lecz w wielu wypadkach jeste- 
śmy skazani na niepowodzenie. Często teksty w prasie drugoobiegowej nie były w ogóle podpisywane. Wówczas pomóc mogąjednie świadkowie, ale i oni często nie są w stanie przyporząakować tekstów poszczególnym autorom. Próbujemy wraz z pytaną osobą rozpoznać pseudonimy i cały zespół piszący. Dzięki rozmowie następuje swoiste „rozszyfrowanie” czy zdekodowanie badanego tytułu.

Na koniec ważne pytanie. Kiedy zająć się szczegółowo analizą źródeł znajdujących się w archiwach? Mamy dwa rodzaje miejsc, gdzie należy szukać materiałów na temat drugiego obiegu. Pierwsze to archiwalia gromadzące wszelkiego rodzaju wytwory podziemne. W Gdańsku jest to Europejskie Centrum Solidarności, Archiwum Komisji Krajowej NSZZ „Solidarność”, w Warszawie Biblioteka Narodowa i Ośrodek KARTA, w Krakowie Fundacja Centrum Dokumentacji Czynu Niepodległościowego. W tych miejscach znajdziemy źródła prasowe, wytwory podziemnych twórców, uzyskamy kontakty do wielu osób z podziemia. W ECS znajduje się blisko 900 notacji z uczestnikami opozycji demokratycznej i działaczami Solidarności. Jeśli jednak chcemy uzyskać materiały dotyczące struktury organizacyjnej środowisk opozycyjnych, problemów wydawniczych, rozpracowania uczestników drugiego obiegu, aresztowań, agentury etc., znajdziemy je praktycznie wyłącznie w archiwum Instytutu Pamięci Narodowej. Niestety, wobec masowego niszczenia dokumentów na przełomie 1989 i 1990 roku sporo informacji się nie zachowało bądź jesteśmy skazani na łowienie ich strzępków i układanie w całość. Zanim złoży się wniosek kwerendalny do IPN, warto rozpoznać jak najwięcej szczegółów dotyczących badanej problematyki. Znając imiona i nazwiska twórców pisma, posiadając jakieś szczegółowe informacje na temat badanego tytułu, warto oczywiście złożyć wniosek jak najszybciej, aby uzyskać materiały, które można przebadać jeszcze przed planowaną rozmową z uczestnikami podziemnej działalności. Dokumenty należy również omawiać ze świadkami, nie bać się trudnych pytań, weryfikacji danych. Można w analizie przedstawić kilka stanowisk i stawiać samodzielnie hipotezy badawcze poparte żelazną logiką i argumentami, a nie insynuacjami czy emocjami. Trudniej jest, gdy szczegółów brak i nie możemy wpisać we wniosku do IPN żadnych konkretów. Wówczas lepiej złożyć taki wniosek po rozmowie, uwzględniając wiedzę zdobytą podczas wywiadu. Bardzo często sami uczestnicy drugiego obiegu posiadają sporo kopii dokumentów, które mogą pomóc w ustaleniu ważnych faktów i naprowadzić na pewne dane. Po analizie materiałów archiwalnych często po raz kolejny spotykamy się na rozmowę, aby zweryfikować dane Służby Bezpieczeństwa czy urzędów państwowych.

W rezultacie funkcjonujemy w trójkącie: a) prasa drugiego obiegu, b) twórcy i uczestnicy drugiego obiegu, c) materiały archiwalne czy operacyjne na temat samego zjawiska. Układając to wszystko jak puzzle, jesteśmy w stanie uzyskać obraz przeszłości, będący w jakiejś mierze zwierciadłem ówczesnej rzeczywistości. Powstaje opracowanie opisujące ważny fragment najnowszej historii Polski i walki z komunizmem. Co ważne, ostateczna wersja tekstu jest omawiana $\mathrm{z}$ uczestnikami drugiego obiegu, autor musi wiele fragmentów skonsultować, 
poprawić, uzupełnić, być otwarty na zmiany. I nie chodzi tu o pójście na „zgniłe kompromisy" czy o cenzurę, tylko o logiczne argumenty świadków historii i niedoskonały osąd spraw przez badacza - wynikający z prostego faktu, że w tych wydarzeniach nie uczestniczył. Podczas całej mojej drogi naukowej nigdy nie zdarzyło mi się napisać czegoś, z czymś się nie utożsamiam, nie zgadzam; nie musiałem niczego z tekstów usuwać ani na siłę dodawać pod wpływem gorących próśb świadków. Zaś dzięki wzajemnemu zrozumieniu wagi opisu historycznych wydarzeń udaje się udoskonalać tworzone opracowania.

$\mathrm{Na}$ zakończenie badania następuje zawsze próba, pełna bądź szczątkowa, ustalenia roli i znaczenia danego tytułu prasowego i stojących za nim ludzi czy środowiska, określenia zasięgu oddziaływania. Bibuła, świadkowie i dokumenty przynoszą dane nie tylko o nurtach tematycznych, gatunkach publicystycznych, w obrębie których poruszali się autorzy, ale również o tym, jakie miało to znaczenie. Nie wykonywałem dotychczas badań statystycznych nad drugim obiegiem (samymi badaniami dotyczącymi drugiego obiegu raczej nie dysponujemy). Mogłyby one w jakimś stopniu pomóc w ustaleniu czytelnictwa podziemnej prasy, np. w Trójmieście. Czas pokaże, czy uda się zorganizować takie przedsięwzięcie.

\section{Przykład badawczy (case study)}

Na zakończenie chciałbym podać przykład realizacji holistycznego podejścia do prasy drugiego obiegu. W 2013 roku postanowiłem zająć się Strajkowym Biuletynem Informacyjnym Solidarność, który ukazywał się między 23 a 31 sierpnia 1980 roku w trakcie historycznego strajku w Stoczni Gdańskiej im. Lenina zakończonego podpisaniem porozumień $\mathrm{z}$ władzami. Na początku zgromadziłem materiały na temat historii Biuletynu. Było tego bardzo niewiele, głównie wspomnienia twórców pisma zamieszczone na stronach internetowych (Konrad Bieliński, Krzysztof Wyszkowski, Mariusz Wilk) oraz nieco informacji zawartych w bogatej literaturze przedmiotu na temat strajku sierpniowego. Odnalazłem jeden niewielki tekst $\mathrm{w}$ znacznej części dotyczący problematyki pisma (Sandecki 2010, s. 194-197). Sam Biuletyn został zdigitalizowany już przez trzy instytucje: Bibliotekę Uniwersytetu Gdańskiego, Ośrodek KARTA i Europejskie Centrum Solidarności. W żadnym przypadku pliki nie zostały poddane OCR, toteż nie ma możliwości wyszukiwania pełnotekstowego. Jakość wersji cyfrowej materiału określiłbym jako średnią. Archiwum filmowe Europejskiego Centrum Solidarności udostępniło mi notacje z Konradem Bielińskim, Janem Barańskim, Mirosławem Chojeckim, Ewą Milewicz. Kolejnym etapem była szczegółowa analiza treści i zawartości pisma. Umożliwiła ona wytypowanie najważniejszych kategorii - nurtów tematycznych znajdujących się na łamach Biuletynu (udało się skategoryzować 41 na 51 stron).

Opracowałem szczegółowy kwestionariusz pytań do twórców tytułu. W planie było wywołanie czterech notacji z redakcją pisma: Konradem Bielińskim, Ewą 
Milewicz, Mariuszem Wilkiem i Krzysztofem Wyszkowskim. Udało się przeprowadzić dwie pierwsze. Szczególnie cenna była ponaddwugodzinna rozmowa $\mathrm{z}$ twórcą pisma Konradem Bielińskim. Przy okazji badania udało się również porozmawiać z Mirosławem Chojeckim i Mirosławem Rybickim na temat funkcjonowania poligrafii strajkowej w pierwszych dniach stoczniowego protestu. Nie były to notacje biograficzne czy etnograficzne, lecz tematyczne i dotyczyły okresu między 14 a 31 sierpnia. Przy okazji badania Biuletynu udało się również ustalić wiele ważnych szczegółów dotyczących samego strajku w Stoczni Gdańskiej w 1980 roku. Przy opracowaniu zostały również wykorzystane materiały operacyjne SB o kryptonimie „Brama”, które znajdują się w archiwum Instytutu Pamięci Narodowej. Dzięki temu udało się „rozpracować” twórców pisma, ich role, wpływ na zawartość, metody pracy. Dzięki analizie Biuletynu i notacjom możliwe było szczegółowe opisanie genezy pisma, ustalenie, co ono komunikowało, za pomocą jakich środków i w jaki sposób. Wspomnienia twórców, ale i mieszkańców Trójmiasta oraz dostępne publikacje pozwoliły określić, do kogo kierowany był tytuł i jaką miał skuteczność oddziaływania - biorąc pod uwagę jego rekordowy, jak na ówczesne czasy, nakład 40 tys. egz. Szczególnie cenne byłyby badania ankietowe wśród mieszkańców Gdańska czy Trójmiasta na temat recepcji pisma. Ze względów finansowych i organizacyjnych realizacja takiego badania okazała się niemożliwa. Opracowanie samego Biuletynu udało się w części opublikować w 2015 roku (Knoch 2015). Co ważne, zanim tekst się ukazał, został poddany weryfikacji merytorycznej i autoryzacji przez Konrada Bielińskiego, Mirosława Chojeckiego i Ewę Milewicz.

\section{Bibliografia}

Bibuła 4. Kultura niezależna w Polsce 1976-1989 - droga do niepodległości, Czerwiec 2006.

Dubiel P. (1969). Metoda analizy zawartości prasy. W: M. Kafel (red.). Metody i techniki badawcze w prasoznawstwie, t. I (s. 9-112). Warszawa.

„Drugi Obieg” - plusy i minusy. Z Dawidem Warszawskim rozmawia Krzysztof Czabański. Kultura, nr 6/501, Paryż 1989.

Filipkowski P. (2005). Historia mówiona i wojna. W: S. Buryła, P. Rodek (red.). Wojna. Doświadczenie i zapis. Nowe źródła, problemy, metody badawcze (s. 13-35). Warszawa.

http://www.ecs.gda.pl/title,Notacje_filmowe,pid,389.html.

Kafel M. (1969). Prasoznawstwo. Warszawa.

Knoch K. (2015). Strajkowy Biuletyn Informacyjny Solidarność. W: M. Łosiewicz, A. Ryłko-Kurpiewska (red.). Media, biznes, kultura, t. 2: Społeczna i polityczna rola mediów (s. 163-182). Gdynia.

Łabędź K. (1997). Spory wokół zagadnień programowych w publikacjach opozycji politycznej w Polsce w latach 1981-1989. Kraków.

Łosiewicz M., Ryłko-Kurpiewska A. (red.) (2015). Społeczna i polityczna rola mediów. Gdynia.

Materiały przygotowane w 2014 r. przez Tomasza Parkołę z Poznańskiego Centrum Superkomputerowo-Sieciowego na potrzeby projektu naukowego „Drugi obiegi w Trójmieście w latach 1976-1989". 
Nowak K. (2011). Metodologia oral history. Kultura i Historia, 20.

Pisarek W. (1983). Analiza zawartości prasy. Kraków.

Rudka Sz. (2001). Poza cenzurą. Wrocławska prasa bezdebitowa 1973-1989. WarszawaWrocław.

Sandecki M. (2010). Pierwsze gazety wolności. W: M. Drzewiecki, M. Ręczmin (red.). Narodziny Solidarności. Kroniki sierpniowe (s. 191-197). Gdańsk.

Siekierski S. (1992). Drugi obieg. Uwagi o przyczynach powstania i społecznych funkcjach. W: J. Kostecki, A. Brodzka (red.). Piśmiennictwo - systemy kontroli - obiegi alternatywne, t. 2 (s. 285-296). Warszawa.

Sowiński P. (2011). Zakazana książka. Uczestnicy drugiego obiegu 1977-1989. Warszawa 2011.

Swierczyńska D. (red.) (1995). Kto był kim w II obiegu: słownik pseudonimów pisarzy i dziennikarzy 1976-1989. Warszawa.

\section{STRESZCZENIE}

Prasa drugiego obiegu jest jednym z najważniejszych źródeł historycznych do opisywania najnowszych dziejów Polski. W badaniach postuluje się ujęcie holistyczne, tzn. całościowe opracowania poszczególnych tytułów prasowych lub wyczerpujące tematyczne analizy porównawcze, wykonywane przez dobranie możliwie szerokiej próby badawczej. W pierwszym etapie należy przeprowadzić szerokie kwerendy celem ustalenia faktycznego stanu badań nad interesującym nas zagadnieniem. W drugim należy dokonać bardzo szczegółowej analizy treści i zawartości danego bądź danych tytułów prasowych, dzięki której opracowujemy tematyczne klucze kategoryzacyjne. Do każdego tematu - klucza przyporządkowujemy wybrane teksty. Następnie mierzymy powierzchnię poszczególnych tekstów z danego tematu, np. za pomocą liczby stron czy $\mathrm{w} \mathrm{cm}^{2}$. Wykonujemy zestawienia statystyczne służące jako punkt wyjścia do analizy merytorycznej prasy drugiego obiegu. W prasie szukamy również informacji na temat genezy ukazania się pism, osób czy środowisk je wydających, problemów organizacyjnych itp. „Rozmowa” badacza z prasą staje się przygotowaniem do rozmowy z jej twórcami, autorami. Następnie rozpoczynamy poszukiwania redaktorów czy podziemnych drukarzy, poprzedzone przygotowaniem możliwie wyczerpującego kwestionariusza pytań. Kolejnym etapem jest wywołanie notacji dźwiękowych lub filmowych z osobami, do których udało się dotrzeć i które często wobec braku materiałów archiwalnych są jednym źródłem informacji umożliwiającym opracowanie losów podziemnych wydawnictw. Badacz staje się pośrednikiem w dialogu między prasą, a jej twórcą. Kolejnym ważnym ogniwem badania nielegalnej działalności wydawniczej jest analiza materiałów archiwalnych, przede wszystkim dokumentów operacyjnych Służby Bezpieczeństwa znajdujących się w zbiorach Instytutu Pamięci Narodowej. Swoisty trójkąt badawczy: opracowanie treści i zawartości prasy, rozmowa z jej twórcami oraz analiza dokumentów archiwalnych pozwala dokonać kronikarskiego zapisu minionej rzeczywistości i ocalić od zapomnienia ważny fragment najnowszej historii Polski.

Slowa kluczowe: drugi obieg, prasa podziemna, samizdat, opozycja demokratyczna, współczesna historia Polski (PRL), oral history 